\title{
Comparative study of the effects of two educational interventions of storytelling and roleplaying on tooth-brushing method in preschool children of Aleshtar city
}

\author{
Hossein Ashtarian ${ }^{1}$, Iman Pouladi $^{2}$, Farsad Jalilian$^{1}$, Afshin Almasi ${ }^{1},{ }^{*}$ Fatemeh Azizi Abi $^{1}$
}

Sri Lanka Journal of Child Health, 2021; 50(2): 246-252

\begin{abstract}
Background: Since the most effective way to remove dental plaques is correct brushing, it seems necessary to teach children how to brush their teeth correctly.
\end{abstract}

Objectives: To compare the effects of two educational programmes of storytelling and roleplaying on tooth-brushing method among preschool children.

Method: This semi-empirical study was carried out on preschool children in Aleshtar city. At first, using random blocks method, the preschools were divided into three groups of storytelling, roleplaying and control. Then samples were prepared in an available sampling method. Data collection tools included demographic data questionnaire, brushing knowledge assessment questionnaire and brushing skill assessment checklist. Storytelling and roleplaying were taught to children in 4 training sessions of 45-60 minutes during a week and questionnaires were completed before and after training. Finally, data were analysed using SPSS version 22. $\mathrm{p}<0.05$ was considered as the level of significance.

Results: The study subjects included 90 children aged 6 years, of whom $48(53.3 \%)$ were boys. There was no significant difference between the two groups in terms of average score of brushing knowledge and skill before training $(p>0.05)$. After training, the average score of brushing knowledge

${ }^{1}$ Health Promotion and Education Department, Health Faculty, Kermanshah University of Medical Sciences, Kermanshah, Iran, ${ }^{2}$ Department of Medical Microbiology, Faculty of Medicine, Lorestan University of Medical Sciences, Khorramabad, Iran.

*Correspondence: fatemehaziziabi@gmail.com

https://orcid.org/0000-0001-9291-849X (Keceived on 14 May 2020: Accepted after revision on 19 June 2020)

The authors declare that there are no conflicts of interest

Personal funding was used for the project.

Open Access Article published under the Creative

Commons Attribution CC-BY (c) (i) License and skill in the roleplaying group was significantly higher than in the control and storytelling groups while the scores in the storytelling group were significantly higher than in the control group ( $p$ $<0.001$ ). In the roleplaying and storytelling groups, the average scores of brushing knowledge and skill in children increased meaningfully $(\mathrm{p}<0.001)$. But in the control group, no significant variation was observed $(p>0.05)$. There was a significant positive correlation between the knowledge and skill of brushing $(\mathrm{p}<0.001$.).

Conclusions: The educational programme of roleplaying exhibited higher effectiveness in increasing brushing knowledge and skill, compared to the educational programme of storytelling.

DOI: http://dx.doi.org/10.4038/sljch.v50i2.9565

(Key words: Roleplaying, storytelling, brushing, preschool students)

\section{Introduction}

Compared to other parts of the body, the mouth needs more protection ${ }^{1}$. The World Health Organisation (WHO) considers oral hygiene as a part of general health ${ }^{2}$. In addition to dental caries, oral hygiene negligence can cause consequences such as gingivitis, endocarditis, halitosis, dental irregularities and also less confidence and lower life quality ${ }^{3,4}$. Furthermore, this problem affects feeding, speaking and sound quality ${ }^{5,6}$. Children's dental and oral hygiene is highly important because it influences the development, weight, confidence, socialization and learning capabilities of children ${ }^{7}$. Children are founders of a society's future and their socio-physical health promises a better future ${ }^{8}$.

Treatment of oral-dental diseases is too costly, so it is essential to find a preventive approach ${ }^{9}$. Prevention of tooth decay and dental diseases requires the implementation of self-protective behaviours including the use of dental floss, brushing, fluoride therapy and regular referral to the dentist ${ }^{10,11}$. Since dental plaque accumulation (a set of bacteria in carbohydrate matrices) is the most important cause of tooth decay, periodontitis and gingivitis ${ }^{12}$, daily removal of plaques mechanically is the only practical way to improve dental hygiene in the long term ${ }^{13}$, and tooth-brushing is the most important mechanical procedure to control $\mathrm{it}^{14}$. 
Therefore, one of the most important steps in this area is to develop such a skill in the child ${ }^{15}$. Studies have shown that only $21 \%$ of children possess appropriate brushing skill ${ }^{16}$, so it seems that the best strategy for oral hygiene is developing correct brushing skill in children ${ }^{17}$.

Recent studies in USA have demonstrated that teaching preventive behaviours like using brushes and floss and regular visits to a dentist, during recent decades have increased the number of people who could protect their natural teeth in older ages ${ }^{6,18}$. Moreover, it has been observed that children who follow the principles of oral hygiene from younger ages, do this in older ages, too ${ }^{19}$. The environment of the school or kindergarten, as an available place for children, is especially important to implement oral hygiene interventions ${ }^{20}$. It appears that health training based on new learning methods in a non-conflicting joyful environment is a short path to enhance children's oral hygiene ${ }^{21}$.

The educational programmes of storytelling and roleplaying are new, innovative and effective methods but the superiority of one over the other is not known yet. Also, the effectiveness of these programmes in teaching the correct technique of brushing has not been studied ${ }^{22,23}$. Storytelling is a particular educational method which helps people by making them interested in creating imaginative pictures and having a dynamic thinking. Through stories, related events and concepts are placed in a framework leading to a better understanding and recalling information in future ${ }^{21,24,25}$. Storytelling is more exciting than direct work with children due to their interest in stories. As a consequence, it increases children's concentration, does not entail educational conflict and concern about performance and provides generalization best $\mathrm{t}^{26}$. However, in Iran, no study has yet been conducted to compare the effects of two educational programmes of storytelling and roleplaying on preschool children's tooth-brushing.

\section{Objectives}

The present study was conducted to compare the effects of two educational programmes of storytelling and roleplaying on tooth-brushing method among preschool children.

\section{Method}

Sampling: This semi-empirical study was carried out on preschool children in Aleshtar city from October 2018 to September 2019. With about 35 thousand population in Lorestan province, Aleshtar contained 57 preschool students during the time of the study. The inclusion criteria of the study were: the consent of one of the parents and the individual's non-participation in training classes of oral hygiene in the past. Non-attendance in educational classes and mental-physical disabilities were the exclusion criteria. Using sextet randomized blocks sampling method the preschools were divided into three groups of storytelling (intervention group 1), roleplaying (intervention group 2) and non-training (control) in a way that each group contained 5 centres. According to previous studies, taking into account the reliability level of $95 \%$ and test power of $80 \%$ using PASS 12 software, minimum required sampling volume in each group was 30 subjects considering the sample drops probability.

Data collection tools: In this study three tools were used: demographic data questionnaire, knowledge assessment questionnaire and brushing skill assessment checklist. The demographic data questionnaire included age, gender, parent educational level, family's economic status and the number of family members. Knowledge assessment questionnaire contained 7 questions which had been designed visually to be understandable to preschool students. The questions in this questionnaire were about the age of primary tooth eruptions, useful nutrition for teeth, the number of times of brushing daily, the primary stage of brushing, the part of tooth which should be brushed, the amount of used toothpaste and take or not take the toothpaste. One point was assigned to each true answer; as a result the range of points was 0 to 7 . The content of this questionnaire had been derived from available scientific sources such as articles and textbooks. The content validity rate (CVR) of this questionnaire had been determined by 7 dentists and 4 faculty members of health training group. The average CVR was 0.7 , and CVR averages for simplicity, specificity and clarity were 87,88 and 84 respectively. The questionnaire reliability on 15 participants using Cronbach alfa method was 0.81 . The brushing skill checklist also contained 7 practical items. To perform each action correctly 2 points, relatively correctly 1 point and for each incorrect action 0 point was assigned. So, the range of points for each participant varied from 0 to 14 . The applied parameters in this checklist were 7 conditions which had been applied to examine true brushing skill in 5-6 year old children $^{27}$. The Farsi version of this checklist had been confirmed in a study by Mahmoodi $\mathrm{P}$, et $a l^{16}$.

Implementation: At first, the required explanations about the study were given to the participants and the demographic data questionnaire was completed for students. The assessment of children's knowledge and skill was done in two stages (preand post-training) by an experimenter who recorded the consequences without any knowledge about the way participants were assigned to each group. It was organized as follows: children entered the classroom one by one with their trainer. 
After some greeting to make relationship and to reduce probable stress among children, a new toothbrush was given to each child and he was asked to start brushing his teeth in front of the researcher. The evaluator assigned a point to each parameter by assessing the child's way of brushing based on the checklist questions

Educational interventions: Participants in roleplaying and storytelling groups were trained in 4 sessions of 45-60 minutes with different titles (introducing dental structure, tooth decay training, prevention of tooth decay and correct brushing training) during a week. This content was equal for both groups. In the roleplaying group, the children were asked to perform the correct way of brushing by roleplaying after researcher's performance. In the storytelling group, the correct way of brushing was narrated as a story for students by a trained expert in performing arts ${ }^{21,22,25,26}$.

Ethical issues: Ethics clearance was obtained from the Research Ethics Committee of Kermanshah University of Medical Sciences (No. IR/KUMS/REC/1397/836). Participation in the research was voluntary and consciously written consent was taken from all participant's parents. They were assured that the children's information will be secured by the research group.
Statistical analysis: To analyse data considering data normalisation, the following tests were used: Kruskal-Wallis statistical test to compare dependent variables between groups, MannWhitney test for two groups follow up comparison, Wilcoxon test to compare variables before and after the intervention, Chi square test to study the relationships between qualitative variables and Spearman non-parametric correlation coefficient to study the relationship between dependent variables. The statistical software was SPSS 22. In all statistical tests $p<0.05$ was considered as the level of significance.

\section{Results}

In total, 90 children aged 6 years, including 48 $(53.3 \%)$ males and $42(46.7 \%)$ females participated in this research. Table 1 shows the study subjects' frequency distribution for gender, parents' education, family economic status and family dimension.

According to table 1 there was no significant difference in terms of demographic variables among the three groups.

Table 2 compares the average scores of brushing knowledge and skill in the 3 groups.

Table 1: Study subjects' frequency distribution for gender, parents' education, family economic status and family dimension

\begin{tabular}{|c|c|c|c|c|}
\hline \multirow[t]{2}{*}{ Variables } & \multicolumn{3}{|c|}{$\begin{array}{c}\text { Groups } \\
\text { Frequency (\%) }\end{array}$} & \multirow[t]{2}{*}{ p-value } \\
\hline & Control & Roleplaying & Storytelling & \\
\hline $\begin{array}{l}\text { Gender } \\
\text { Boy } \\
\text { Girl }\end{array}$ & $\begin{array}{l}14(46.7) \\
16(53.3) \\
\end{array}$ & $\begin{array}{l}16(53.3) \\
14(46.7) \\
\end{array}$ & $\begin{array}{l}18(60.0) \\
12(40.0) \\
\end{array}$ & $\mathrm{p}=0.875$ \\
\hline $\begin{array}{l}\text { Father's educational level } \\
\text { Diploma } \\
\text { AA/MA } \\
\text { Dr. }\end{array}$ & $\begin{array}{c}12(40.0) \\
18(60.0) \\
0(0.0)\end{array}$ & $\begin{array}{l}20(66.7) \\
09(30.0) \\
01(03.3)\end{array}$ & $\begin{array}{c}15(50.0) \\
15(50.0) \\
0(0.0)\end{array}$ & $\mathrm{p}=0.084$ \\
\hline $\begin{array}{l}\text { Mother's educational level } \\
\text { Under diploma } \\
\text { Diploma } \\
\text { AA/MA }\end{array}$ & $\begin{array}{l}01(03.3) \\
14(46.7) \\
15(50.0) \\
\end{array}$ & $\begin{array}{l}01(03.3) \\
17(56.7) \\
12(40.0) \\
\end{array}$ & $\begin{array}{l}01(03.3) \\
14(46.7) \\
15(50.0) \\
\end{array}$ & $\mathrm{p}=0.947$ \\
\hline $\begin{array}{l}\text { Economic status of family } \\
\text { Weak } \\
\text { Moderate } \\
\text { Good }\end{array}$ & $\begin{array}{l}01(03.3) \\
20(66.7) \\
09(30.0)\end{array}$ & $\begin{array}{l}01(03.3) \\
23(76.7) \\
06(20.0)\end{array}$ & $\begin{array}{c}0(0.0) \\
22(73.3) \\
08(26.7) \\
\end{array}$ & $\mathrm{p}=0.768$ \\
\hline $\begin{array}{l}\text { Number of family members } \\
3 \text { subjects } \\
4 \text { subjects } \\
5 \text { subjects }\end{array}$ & $\begin{array}{l}16(53.3) \\
12(40.0) \\
02(06.7)\end{array}$ & $\begin{array}{l}11(36.7) \\
15(50.0) \\
04(13.3) \\
\end{array}$ & $\begin{array}{l}16(53.3) \\
12(40.0) \\
02(06.7) \\
\end{array}$ & $\mathrm{p}-=0.789$ \\
\hline
\end{tabular}


Table 2: Comparing average scores of brushing knowledge and skill in the three groups

\begin{tabular}{|c|c|c|c|}
\hline \multirow[t]{2}{*}{ Groups intervention } & \multicolumn{2}{|c|}{$\begin{array}{c}\text { Knowledge score } \\
\text { SD } \pm \text { mean }\end{array}$} & \multirow[t]{2}{*}{ Statistical test results $\#$} \\
\hline & Before intervention & After intervention & \\
\hline Storytelling & $3.70 \pm 1.05$ & $6.20 \pm 0.40$ & $\mathrm{p}<0.001$ \\
\hline Roleplaying & $3.86 \pm 0.57$ & $6.93 \pm 0.36$ & $\mathrm{p}<0.001$ \\
\hline Control & $3.80 \pm 0.84$ & $3.73 \pm 0.73$ & $\mathrm{p}=0.539$ \\
\hline Statistical test results & $\mathrm{p}=0.551$ & $\mathrm{p}<0.001$ & \\
\hline \multirow[t]{2}{*}{ Groups intervention } & \multicolumn{2}{|c|}{$\begin{array}{c}\text { Knowledge score } \\
\text { SD } \pm \text { mean }\end{array}$} & Statistical test results \\
\hline & Before intervention & After intervention & \\
\hline Storytelling & $5.00 \pm 0.83$ & $9.56 \pm 1.07$ & $\mathrm{p}<0.001$ \\
\hline Roleplaying & $5.23 \pm 0.93$ & $10.26 \pm 1.11$ & $p<0.001$ \\
\hline Control & $4.80 \pm 1.03$ & $4.46 \pm 0.89$ & $\mathrm{p}=0.092$ \\
\hline Statistical test results & $\mathrm{p}=0.154$ & $\mathrm{p}=0.001$ & \\
\hline
\end{tabular}

According to table 2, before training, the average score of brushing knowledge and skill in the three groups did not show a significant difference statistically $(\mathrm{p}>0.05)$. After training, a significant difference was observed between groups in terms of brushing knowledge $(\mathrm{p}<0.001)$. The pairwise comparison of groups showed that the average scores of brushing knowledge and skill in roleplaying group was significantly higher than storytelling and control groups $(p<0.001)$ and it was higher in storytelling group than control group $(\mathrm{p}<0.001)$. The pairwise comparison of brushing knowledge score before and after training in each group showed that the score of knowledge and skill in storytelling group $(\mathrm{p}<0.001)$ and also in roleplaying group $(p<0.001)$ had increased meaningfully but no significant change was observed in the control group $(p>0.05)$. Other findings in this study revealed that there is a positive correlation $(\mathrm{r}=0.754)$ between knowledge of brushing and brushing skill in preschool students $(\mathrm{p}<0.001)$.

\section{Discussion}

In this research no significant difference was observed between demographic variables and brushing knowledge and skill. Similarly, Mahmoodi $\mathrm{P}$, et l $^{16}$ studying 6-year-old children showed that the type of preschool (public or nonpublic), place of birth, number of family members, father's educational level, mother's educational level, father's job, mother's job, living place or history of systematic disease in the child had no significant relationship with brushing skill. Pujar P, et $a l^{28}$ similarly concluded that gender was not effective in brushing ability in 6-12 year olds. Afshar $\mathrm{H}$, et $a l^{19}$ also showed that age and gender had no effect on children's plaque index values following educational programmes.

In the present study, the average scores of brushing knowledge for children in storytelling, roleplaying and control groups were 3.70, 3.86 and 3.80 respectively and the average scores of their brushing were 5, 5.23 and 4.80. These values indicate the lower knowledge level and especially brushing skill in children, because on average these subjects just acquired 54.1 percent of total knowledge score and 35.8 percent of total brushing skill score. This was similar to findings by Livny $\mathrm{A}$, et $a l^{29}$. The lower score of children's skill in this research is consistent with studies by Murphey CL, et $a l^{30}$ and Tumarian L, et $a l^{31}$. Fallahinejad GM, et $a l^{32}$ reported the lower level of children's knowledge about oral hygiene as $34.4 \%$.

In our study the average scores of brushing knowledge and skill in the storytelling and roleplaying groups were increased after training. Also after training the average score of knowledge and performance in the roleplaying group was significantly higher than storytelling and control groups, and it was significantly higher in the storytelling group than in the control group. This means that the effect of training in the form of roleplaying is better than storytelling. Results of a study by Shamsaei $\mathrm{F}$, et $a l^{33}$ showed that the roleplaying model can enhance oral hygiene behaviours in students with mental disabilities.

When telling a story children coordinate and align their imaginations with the words and characters of the story, thereby choosing behaviours which entail social respect and encouragement ${ }^{34}$. Abaresi $\mathrm{R}$, et $a l^{26}$ stated that training social skills via storytelling improves social development and encourages disabled children to be socialized. This supports our findings. According to the conducted studies it seems that up to now no study has been done to compare two storytelling and roleplaying programmes to teach brushing for preschool children. Srivastava N, et $a l^{35}$ compared 3 educational methods of brushing via audiovisual lecture and instructional guidelines related to the correct way of brushing (children as an example). Results showed that maximum and minimum decrease in dental plaque index was observed in the second and third groups, respectively. 
The present study had some limitations. Our criterion to confirm child's ability for brushing was that they reached the brush to the target area and do the brushing. The effectiveness of brushing method had been assessed considering dental plaque index and microbial plaque.

\section{Conclusions}

Results of this study showed that before training the level of knowledge and skill of brushing in preschool children had not been desirable. Although both educational programmes of storytelling and roleplaying increased the level of brushing knowledge and skill considerably, roleplaying performed better than storytelling.

\section{Acknowledgments}

This paper is derived from MA thesis in health training major from medical science university of Kermanshahan with 1397.836 ID. The authors thank vice chancellor of Research and Technology of this university for program enactment and executive, financial supports. Authors also thank parents, preschool students and all participants in this research

\section{References}

1. Tsai AI, Chen CY, Li LA, Hsiang CL, Hsu KH. Risk indicators for early childhood caries in Taiwan. Community Dentistry and Oral Epidemiology 2006; 34(6):437-45.

https://doi.org/10.1111/j.16000528.2006.0 0293.x

PMid: 17092272

2. Shamsi M, Hidarnia A, Niknami S, Karimi M. The effect of educational programs on knowledge and preventive behaviour about dental decay in pregnant women in Arak. Daneshvar 2013; 20(103): 71-85.

3. Hatami H, Razavi S, Eftekhar A. Ministry SMJ of Health and Medical Education (IR-Iran). 1st ed. ed. Tehran: Derakhshan Publication; 2004.

4. Muirhead V, Marcenes W. An ecological study of caries experience, school performance and material deprivation in 5-year-old state primary school children. Community Dentistry and Oral Epidemiology. 2004; 32(4):265-70.

https://doi.org/10.1111/j.16000528.2004.0 0147.x

PMid:15239777
5. Greenspan D. Oral health is global health. Journal of Dental Research 2007; 86(6): 485.

https://doi.org/10.1177/154405910708600

601

PMid: 17525345

6. Peyman N, Samiee Roudi K. The effect of education based on the theory of planned behaviour on caries prevention of permanent teeth in fifth grade students in Khaf city. Journal of Mashhad Dental School 2015; 39(2):123-36.

7. Soltani R. Mothers'knowledge and attitude on oral health preschool children in isfahan, Iran. Health System Research Journal 2013; 9(7):712-9.

8. Ajami B, Shabzendehdar M, Asadollahi A. Evaluation of oral health knowledge, attitude and behaviour of employees in Mashhad health centers No 1, 2 and 3 in 2006. Journal of Mashhad Dental School 2008; 32(1):37-40.

9. Burket LW, Greenberg MS, Glick M. Burket's oral medicine: diagnosis \& treatment: PMPH-USA; 2003.

10. Nyvad B, Robinson C, Ten Cate J. Cariology in the 21st Century: State of the Art and Future Perspectives-50th Anniversary ORCA Congress, Konstanz, July 2003: S. Karger AG.; 2004. https://doi.org/10.1159/isbn.978-3-31801109-8

11. Amini K, Amini A, Madani $\mathrm{H}$, Poormeamari M, Fallah R. The study of styles of oral self-care in Zanjan high school students. Journal of Zanjan University of Medical Sciences 2006; 54: 47-55.

12. Shirmohammadi A, Faramarzie M. The effect of the oral hygiene instruction on awareness, attitude, and practice of a group of patients. Journal of Dentistry 2010; 11(2):173-6.

13. Hendi A, Vadiati SB, Jahandideh Y, Dadgaran I, Nemati S. The Effect of training by standardized student method on decreased dental plaque. Research in Medical Education 2016; 7(4):56-63. https://doi.org/10.18869/acadpub.rme.7.4. 56 
14. Silverman J, Rosivack RG, Matheson PB, Houpt MI. Comparison of powered and manual toothbrushes for plaque removal by 4-to 5-year-old children. Pediatric Dentistry 2004; 26(3):225-30.

15. Casamassimo PS, Casamassimo PS. Paediatric dentistry: infancy through adolescence: Elsevier/Saunders; 2013.

16. Mahmoodi P, Salimi P, Davariashtiani R, Valaii N, Azarshab M, Shafie Zadeh N. Assessment of fine motor skills and tooth brushing skills in 5-6 year olds in Tehran. Journal of Research in Dental Sciences 2014; 11(3):175-80.

17. Buglar ME, White KM, Robinson NG. The role of self-efficacy in dental patients' brushing and flossing: testing an extended Health Belief Model. Patient Education and Counseling 2010; 78(2):269-72. https://doi.org/10.1016/j.pec.2009.06.014 PMid:19640670

18. Ajayia EO, Yetunde OA. Attitudes to malocclusion in a Nigerian school population. Journal of Medicine and Biomedical Research 2006; 5(1): 16-23. https://doi.org/10.4314/jmbr.v5i1.10678

19. Afshar H, Aezami R. Efficacy of educational intervention on plaque index among pre-school children. Iranian Journal of Pediatric Dentistry 2016; 11(2): 51-60.

https://doi.org/10.29252/ijpd.11.2.51

20. St Leger L. Schools, health literacy and public health: possibilities and challenges. Health Promotion International 2001; 16(2): 197-205.

https://doi.org/10.1093/heapro/16.2.197

PMid: 11356758

21. Zarei F. Effects of health education on oral health through role playing and painting on awareness and function of children. Journal of Qazvin University of Medical Sciences 2010; 14(1):92-4.

22. Dorudian Z. The impact of role-playing technique on social adjustment and academic achievement in dyscalculia students of Tehran province, academic year 87-88. Psychol Except Indivd. 2011; 1(2): 85-102.

23. Yassaei S, Davari A, Aghaei M, Ghaffari Targhi M. Comparison two learning methods of oral health education storytelling and speech on elementary school students in Yazd. Journal of Health 2016; 7(1):102-8.

24. Mazloomi-Mahmoodabad S, MoeinTaghavi A, Barkhordari A, Alidoosti F. Effect of role modeling through theater show in oral health education. Journal of Islamic Dental Association of Iran. 2009; 21(2).

25. Birang R, SHAKERIAN K, Yazdanpanah F, Nadimi M. The effect of education by visual media on oral health promotion of students. Arak Medical University Journal 2006; 9:1-6.

26. Abaresi R, Temuri S. The effect of storytelling and role playing on learning social skills by teachable mentally retarded children. Science Journal of Management Systems 2012; 7(31):1-18.

27. Dulcan MK, Wiener JM. Textbook of Child and Adolescent Psychiatry: American Psychiatric Pub.; 2004.

28. Pujar P, Subbareddy V. Evaluation of the tooth brushing skills in children aged 6-12 years. European Archives of Paediatric Dentistry 2013; 14(4): 213-9. https://doi.org/10.1007/s40368-013-00463

PMid:23737009

29. Livny A, Vered Y, Slouk L, Sgan-Cohen HD. Oral health promotion for schoolchildren-evaluation of a pragmatic approach with emphasis on improving brushing skills. BMC Oral Health. 2008; 8(1): 4 .

https://doi.org/10.1186/1472-6831-8-4 PMid:18237389 PMCid:PMC2253522

30. Murphey CL. Exploring oral health among pregnant and parenting adolescent women: a mixed methods study. Citeseer; 2010.

31. Tumarian L, Suri S, Farhadi H. DMFT Index study of 12 year-old students living in Qom city. Dent Mag Shahid Beheshti University of Medical Sciences 2005; 23: 467-74.

32. Fallahinejad GM, Mirshekar Z, Razavi S. Knowledge and attitude toward oral and dental health among Zahedan's guidance school students. 2007; 24(4): 492-8. 
33. Shamsaei F, Ashtarani E, Meschi M, Ashtarani F. The effect of oral health education through role playing on health behavior of educable mentally disabled boy students in Hamadan. Journal of Nursing Education 2019; 7(1):11-20.

34. Homaei R, Kajbaf M, Siadat S. The effect of telling storeis upon children's adjustment. Journal of Psychological Studies 2009; 5(2): 133-49.
35. Srivastava N, Gupta G, Rana V. A comparative evaluation of efficacy of different teaching methods of tooth brushing in children contributors. Journal of Oral Hygiene and Health. 2013:1-4. https://doi.org/10.4172/23320702.100011 8 